\title{
On Teaching Ethnography in Troubled Times
}

\author{
Andrew M. Gardner \\ University of Puget Sound
}

\begin{abstract}
In this essay, I describe considerations stemming from a field-based ethnographic exercise I utilize in one of the courses which I have designed and which I regularly teach. In my estimation, the contours of the issues I describe here reveal the institutional and ideological parameters of a paradigm that currently dominates contemporary American campuses. I suggest that my experience points to frictions between that seemingly hegemonic academic paradigm and the core values and practices that the discipline of anthropology endeavours to carry into the new millennium. I conclude that this experience, and the institutional practices and ideologies it reveals, portends a difficult future for an anthropologically moored practice of ethnography — one that seeks to systematically and empathically explore the experiences of diverse others in this world.
\end{abstract}

\section{Introduction}

I began teaching anthropology at the University of Puget Sound in Tacoma, Washington in 2005. As a member of a small joint Sociology-Anthropology department offering courses only in sociocultural anthropology, teaching an introductory course in the discipline has been a mainstay in my perennial duties. My department and our university allow faculty the latitude to design and structure courses as we see fit. In the years since my arrival, I've settled on a basic architecture for my rendition of an introductory course in anthropology: students learn about the long and storied history of the discipline, have a chance to ply some ethnographic methods out in the surrounding city, and read and discuss two ethnographic monographs during the second half of the semester. For many students, this course is the only time in their lives they will explore the discipline I love.

To many of its potential students, the fieldwork component of this course is its most attractive element. In the first year I taught the course, students conducted various field observations on campus. Subsequently, we tried riding city buses for the entirety of their route, and later rode elevators up and down the taller buildings in Tacoma in order to analyse the behavioural politics of humans in those compact spaces. After another year of experimentation, I eventually configured a fieldwork assignment around attendance at a nearby megachurch (see Figure 3). After several semesters of success with the assignment, it has become a characteristic feature of my version of our department's introductory course.

I have found this field exercise to be particularly appropriate for students for several reasons. It is logistically advantageous that there are multiple scheduled services every Sunday and several additional services offered throughout the week. This schedule yields some flexibility in constructing a syllabus, and it is a convenient assignment for students to complete amidst the variety of extracurricular obligations typical of their lives. Finally, the church is nearby and open to newcomers, thereby circumventing the challenges to entry that often stymie undergraduate students engaged in first-time fieldwork. 


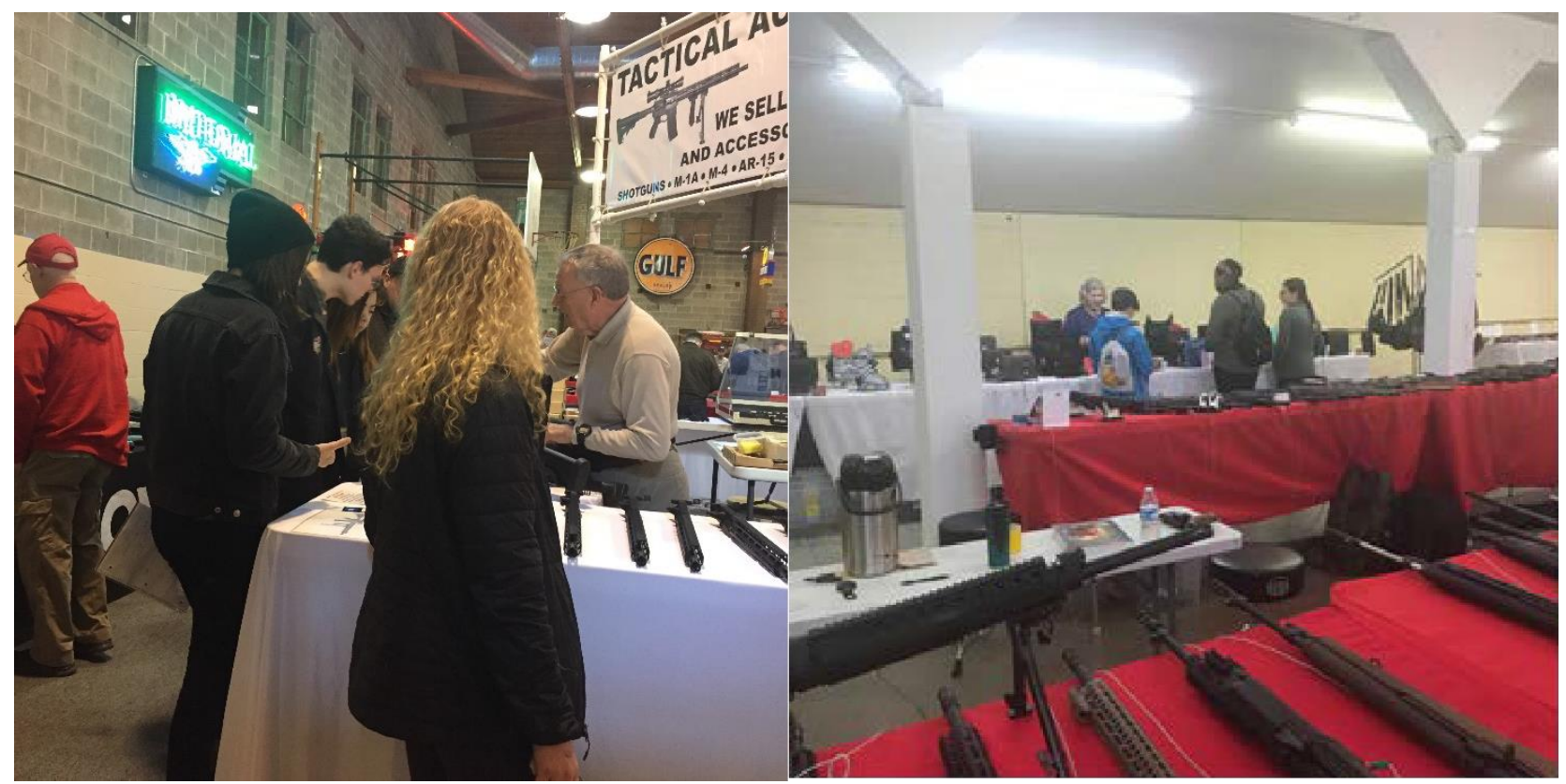

Figures $1 \& 2$ : In a similar field exercise designed to carry these young adults across thresholds of significant difference, students in a more advanced class than the one described in this essay visit a local gun show, interact with the purveyors there, and similarly attempt to discern the story those gun aficionados are telling themselves about themselves, their clients, and the world we all inhabit. Photograph by the author, 2016, 2017.

The service itself provides a rich and multilayered experience, with multiple realms for students' observations and analyses: there are symbolic, textual, ritual, interactional, and demographic features that might draw their analytic attention. After a class discussion of Clifford Geertz's essay on Balinese cockfights, students have several weeks to attend a service and craft a short essay that marshals ethnographic evidence to support an assertion concerning the story these American congregants are telling themselves about themselves, and how they understand their place in the social world. Each year, I receive many papers attentive to the diversity and constitution of the congregation; many students concentrate their attention on community and the sense of belonging that is continually reinforced in most services; some focus on the performative nature of the service and the technological stagecraft involved; others levy their gaze on the profit-seeking nature of the institution and the services it mounts; still, others find altogether novel features of the service to scrutinize with their analytic lens.

In addition to its logistical utility, this assignment satisfies a deeper pedagogic yen I've recently developed. Issues, topics, themes and approaches that were once the domain of anthropology and sociology are now claimed by and central to many other disciplines and departments. Numerous colleagues in a variety of different departments are, nowadays, concerned with race, ethnicity, gender, culture, social organization, and all the other aspects of human diversity that were once principally the purview of sociology and anthropology. Anthropology's methodological toolkit has also proliferated to those disciplines that still require evidence to support their claims and assertions. In short, other mainline disciplines, many ethnic and area studies programs, and numerous other interdisciplinary coagulations envision the conversations, topics and methods that once defined social anthropology as both their own purview and, for some, their raison d'être.

But amidst this shifting academic landscape, and amidst the balkanization of anthropology's concerns into new programs and inter-disciplines, what remains unique to anthropology is its longstanding commitment to crossing thresholds of difference on a voyage toward an informed, empathic, and firsthand understanding of difference. This is the enduring feature of anthropological ethnography, an ideal salvaged from the discipline's colonialist beginnings (see Figure 3). Unlike other disciplines and fields, this encounter with difference is woven into anthropology's DNA. Albeit with notable and valuable exceptions in the ethnographic canon, I suggest that anthropology's unique and enduring contribution is its longstanding commitment to understanding others — others different from ourselves as observing analysts. With that enduring commitment to crossing thresholds of difference comes ethnography, the methodological toolkit designed (and refined over more than a century) to systematically enable and inform such a feat, and historically integral to anthropologists' efforts in combatting eugenics, segregation, racisms and bigotry both here in North America and in many other parts of the globe. 


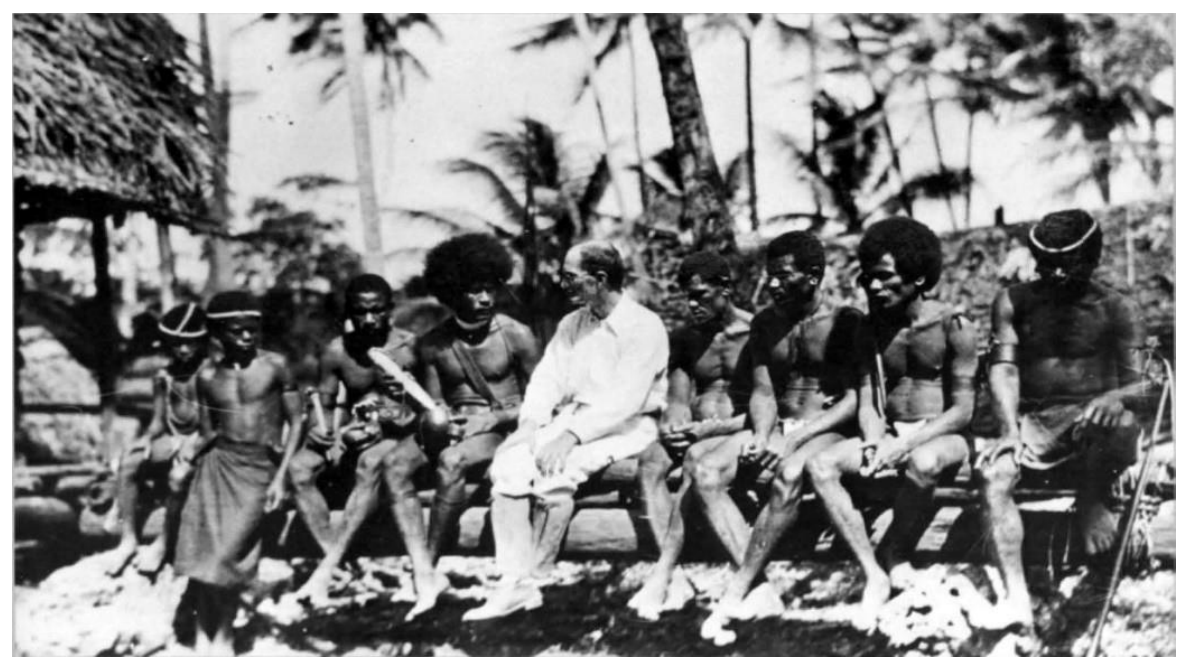

Figure 3: In 1914, Austrian subject and London School of Economics student Bronislaw Malinowski began to await the conclusion of World War One with sustained immersion in village life on the Trobriand Islands of Papua New Guinea, and thereby established the basic template for the ethnographic method that endures to this day. Photo in public domain, from the Wellcome Library, London.

For an expensive liberal arts institution in the Pacific Northwest, a journey to the megachurch provides something that approximates such an experience for most of my students. The church remains a culturally foreign experience to many of the students at Puget Sound. The principal and recurring "learning moment" conveyed in this assignment involves students' analytic journey beyond the simplistic and reactionary critiques that come readily to many progressive and secular young adults in the contemporary United States. In conveying the story which this congregation tells themselves about themselves and the world we all inhabit, I push students to seek some glimmer of ethnographic empathy as they build their analytic, interpretive assertions with data they have gathered.

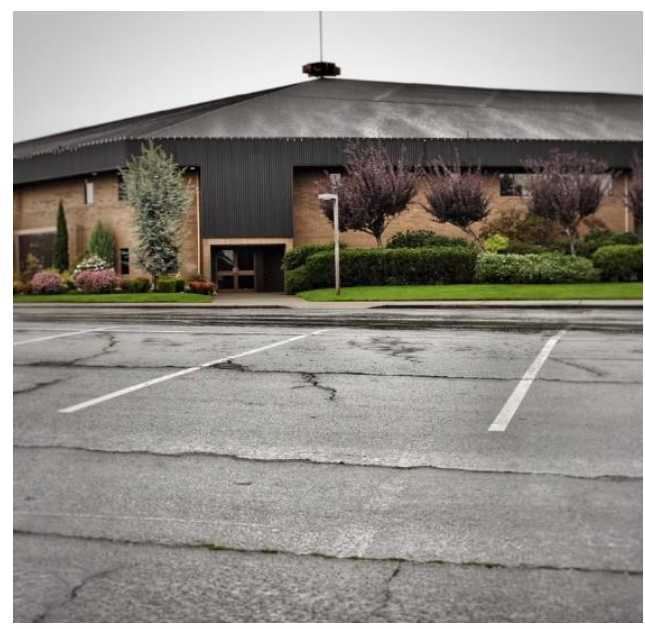

Figure 3: The large church — perhaps the busiest in town — is centrally located, surrounded by an asphalt moat of parking, accessible by public transportation, and offers a variety of services for the diversity of residents in the greater Tacoma area. Photograph by the author, 2018.

In 2017, roughly fifty students in two different sections of the course received this assignment, and collectively they attended various services spread over several weeks. After the second weekend had passed, several students arrived in class with some degree of consternation. The most vocal of those students conveyed that they had been offended by the theme articulated by the megachurch's charismatic minister during his sermon, wherein he (allegedly) trash-talked the Islamic tradition before making his case for the type of salvation provided by Christianity. ${ }^{\mathrm{i}}$ 


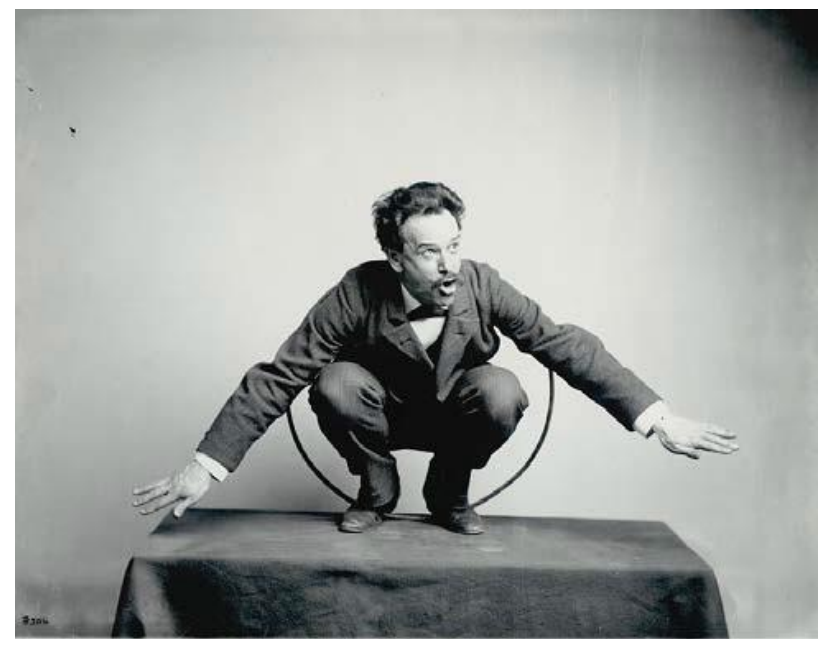

Figure 4: Franz Boas, often conceived as the father of American anthropology, devoted much of his life's efforts to combatting racist policies in early twentieth-century America, and countering the growingly popular eugenics of his time. He and his students were instrumental in the Brown v. Board of Education case and in the racial integration that characterized the mid-century period in the US.

To navigate this consternation, I reiterated to the students what I needed from them. In the papers which were soon due to me, I was seeking some modicum of empathy, understanding, and insight. In what ways were these xenophobic attitudes meaningful to portions of this congregation? What purposes were being served with these representations of Islam? What does this bigotry tell us about how this congregation sees the world and its place in it? And to what extent does the minister speak on behalf of his congregation? Moreover, I reinforced to my students the fact that their experiences provided a rare opportunity: in the prior years when I had used this assignment at the same megachurch, these types of attitudes and sentiments were typically difficult to discern, arduous to analytically excavate, or simply left to the vagaries of interpretation. Never before had students returned to class with such clear and visible evidence of bigotry, I noted to them.

One of those students followed our class discussion with a visit to my office hours. There he reiterated his frustration with what he had encountered at the service, but added that he had also felt afraid. Although not a Muslim himself, he recognized that with his skin and his appearance he could have been mistaken for one, and he conveyed to me that he had felt frightened by the service. In response, I offered my sympathy, confirmed how difficult it was to hear these sorts of things in ethnographic fieldwork, and related a few of the dangerous, sketchy, and disturbing settings I had encountered in my own fieldwork in the Middle East. Then I honed in on the promise I discerned in this scenario: in ethnography, we are the research instrument, and the embodied fear he experienced provided him with an evidentiary foundation to which other students lacked access. This fact yielded him an extraordinary opportunity with the paper soon due to me — the embodied fear he experienced should be central in his analysis, I suggested.

Although the paper he finally turned in was a passable effort, it failed to successfully leverage his experiential evidence into the poignant and critical analysis I envisioned to be possible.

In this and subsequent runs of this exercise I have been struck by the opposition, formal and informal, that students have registered to a kind of ethnographic approach that places students in contexts that may be uncomfortable or even triggering. With this in mind the assignment now comes with the following disclaimer: The goal of this assignment is to cross the threshold of cultural familiarity and to briefly immerse yourself in a cultural world that is unfamiliar to you. For some of you, this setting may be too familiar to serve that function, and we should discuss a possible alternative assignment. For most of you, know that discomfort and unease are a fundamental element of the ethnographic process. Our pedagogic goal, however, does not include feeling afraid or unsafe. Of course, if you encounter any situations that directly threaten your safety, please carefully and immediately exit, and see me at your earliest convenience. 


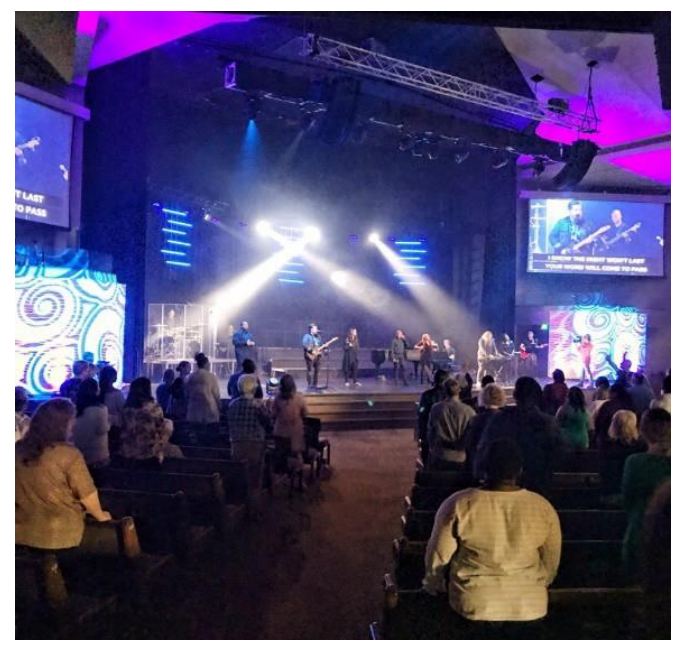

Figure 6: A typical service at the local megachurch is a technologically complex and eventful ritual that seems particularly well configured to contemporary attention spans. It commences with approximately twenty minutes of live Christian adult contemporary music. Photograph by the author, 2018.

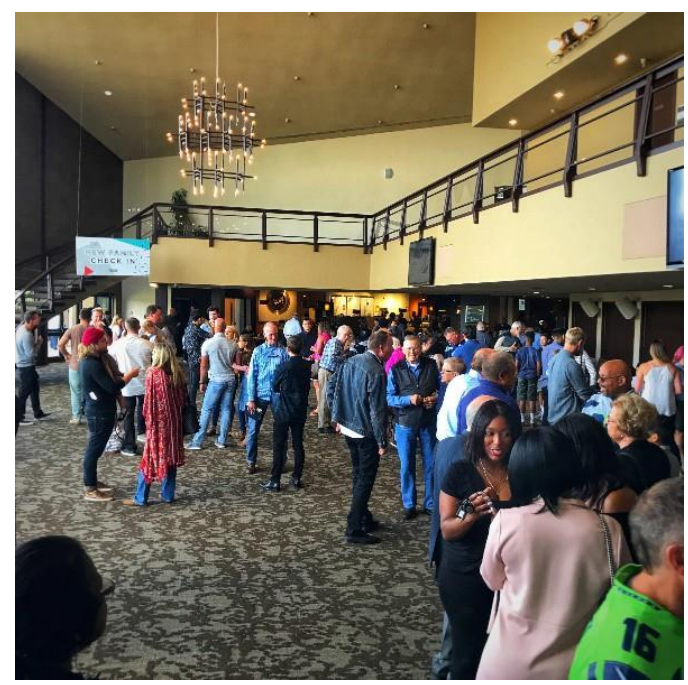

Figure 7: Prior to one of the multiple Sunday services, the congregation gathers in the lobby in anticipation, and the energy in the room is palpable. Photograph by the author, 2018.

What is there to learn from students registering disquiet at the above approach to experiencing ethnography? I understand, foremost, that the lessons I draw from my experience are both partial and relative, in the sense that others may see facets of this scenario that I fail to intuit or grasp. Moreover, I recognize that amidst a period in contemporary America in which my whiteness and my male gender are the most salient characteristics of my identity, there is some appropriate justice to the fact that my understandings are challenged, my assertions are contested, my security is displaced, and that the broad foundations of my positionality continue to erode. I am widely supportive of a social trajectory that might equalize relations in America, and like many anthropologists, my tribal affiliation foremost adheres to the whole of humanity.

Yet none of these sensitivities obviates the responsibilities and privileges woven into a career in academia. For centuries, we have stewarded a set of enduring intellectual conversations through complex, divided, and changing historical circumstances. Indeed, I've come to think of these disciplinary conversations as the keels that steady our path through troublesome seas. For anthropologists, that sustained scholarly conversation long concerned cataloguing and assessing the diversity of human differences that comprise our world, and theorizing how we might think about the human experience in the context of that mosaic of social and cultural difference. These foci were distilled via an ethnographic toolkit developed to systematically facilitate the achievement of those understandings. Those frameworks and those methodologies are central features of the courses we teach, and central features of the pedagogic experience which I have described in this essay. Sadly, however, my experience suggests to me a variety of challenges we face in stewarding anthropology through these fractious times. My concerns and anxieties are threefold. 
First, how will anthropology persevere in an institutional ecosystem increasingly aligned to combat difference rather than engage it? In the United States, anthropology must now be taught in this context — in an environment in which our students are encouraged to divine and report what they perceive to be infractions to the moral order (see Winegard and Winegard 2018). Our courses, our classrooms, and our campuses are the domain for the performance and the development of their budding activist energies. ${ }^{\text {.i }}$

My second concern is a corollary to the first concern: how will anthropology navigate an era in which students' activisms gravitate away from the distant reaches of our complicated and diverse world, and are instead steered to a myopic focus on the campus itself?iii An undeniably valuable commodity, youthful activist energies are now principally directed at the faculty, administrators, and other personnel who comprise the institutions of higher education. And while activisms consigned to campus can be readily recognized as neutered sorts of activism, this is of particular concern to the discipline of anthropology, with the worldly vantage point on global diversity and interaction it promotes.

Thirdly, and finally, over several centuries in pursuit of its scholarly objectives, anthropology has established a substantial and proven track record combatting racism, bigotry, xenophobia, discrimination, and ethnocentricity. In accruing these accomplishments, this discipline has relied heavily on its methodological toolkit: crossing boundaries of difference, engaging that difference, and trying to develop an empathic understanding of otherness has been anthropology's calling card in academia.iv But how will that core mission persevere in the climate of today's ivory tower? In his assessment of the paradigm washing over contemporary academia, Mark Lilla (2017) traces the taproot of contemporary American identity politics to the 1977 Combahee River Collective Manifesto's declaration that "the most profound and potentially most radical politics come directly from our own identity, as opposed to working to end somebody else's oppression." I suggest this atomistic sentiment is motivation for students at once — to "authentically" speak one's own truth, to shun unpalatable difference rather than engage it, and to reject those differences rather than try to understand them.

It is for this last reason, most of all, that I will endeavour to continue with my assignment. Anthropology should never yield the capacity to speak for others. Speaking for others is an indelible feature of our disciplinary tradition, and we achieve those ends through sustained, immersive and necessarily challenging ethnographic fieldwork. We must continue to help students experience the value of these journeys. Our methods have been integral in our disciplinary efforts to combat the racisms, bigotries, and discriminations so readily found in this world. As we wade more deeply into the moralistic cultural politics that define contemporary academia, and as American imperialism continues to erode, perhaps anthropologists should more strenuously trumpet ethnography's capacity to speak about others with understanding and empathy. Maybe this is the central feature of our enduring academic legacy. From a North American vantage point, it seems a tradition more valuable than ever as society continues to fragment into cultural enclaves, ethnic tribes, and a constellation of militant particularisms.

\section{Acknowledgements}

This version of the essay has been heavily redacted by the editorial team, and significant details are missing here. A full version of the essay is available from the author. Concerning that full version: numerous individuals, colleagues, and students have contributed their critiques and perspectives on the reflections I present here. I would particularly like to thank the anonymous reviewers, whose comments really helped improve the draft I originally submitted. Others also merit mention: Rylan Higgins for his editorial prowess which, thanks to our enduring friendship, greatly enhanced this essay; and Zahra Babar, who's seemingly bottomless reservoir of encouragement again proved vital to me. Additionally, numerous colleagues at my institution, and a variety of trusted friends and colleagues elsewhere, provided meaningful feedback on emergent versions of this piece. I'll leave them unnamed. Numerous trusted undergraduate students also read various versions of this essay over the past year, and their perspectives mattered greatly to me. I'll also leave them unnamed here. Finally, my partner Birdie helped steady me through the many tribulations I encountered in the episode I describe. I am so grateful for her and for all the friends and colleagues with whom I think and forge my understandings. Nonetheless, the ideas and sentiments presented here are mine alone. 


\section{References}

Fisher, M. (2013), Exiting the vampire castle. The North Star.

https://www.opendemocracy.net/en/opendemocracyuk/exiting-vampire-castle/

Klein, C. (2017), Opening up the Echo Chamber: Teaching Cultural Competence in Contentious Times. Teaching Anthropology 7(1): 54-61.

Lilla, M. (2017), The Once and Future Liberal. New York: Harper.

Schulman, S. (2018), Conflict is Not Abuse: Overstating Harm, Community Responsibility, and the Duty of Repair. Vancouver: Arsenal Pulp Press.

Whittington, K. (2018), Speak Freely: Why Universities Must Defend Free Speech. Princeton, New Jersey: Princeton University Press.

Winegard, Bo and Winegard, Ben (2018), The Preachers of the Great Awokening. Quillette.

https://quillette.com/2018/09/21/the-preachers-of-the-great-awokening/

\section{Notes:}

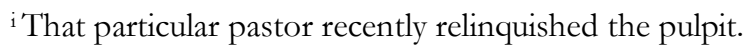

ii Through this performance, students are taught that policing the moral domain on campus is a form of activism. That conflation then frames subsequent interactions with difference.

iii A handful of the many examples are discussed in Whittington (2018).

iv Klein (2018) envisions the same value to ethnography is his recent article. 